\title{
PENERAPAN KONSEP URBAN FARMING-BASED RESILIENT CITY DALAM PENGEMBANGAN KOTA YANG BERKETAHANANAN PANGAN DI KOTA SURAKARTA
}

Ammar Abdurrohman', Fikri Fadly Arkasala², Noviamas Nurhidayah²

1 Program Studi Pengelolaan Hutan, Fakultas Pertanian, Universitas Sebelas Maret

2Program Studi IImu Lingkungan, Fakultas Matematika dan IImu Pengetahuan Alam, Universitas Sebelas Maret

\begin{abstract}
Abstrak
Pengembangan konsep resilient city (kota tangguh) di era pandemi merupakan konsep perencanaan kota yang dapat menjadi perhatian pada saat ini. Konsep kota tangguh tersebut diharapkan dapat menjadi rujukan dalam penggunaan lahan secara efektif dalam pengembangan suatu kota. Sektor pertanian dapat menjadi salah satu komponen dalam pengembangan konsep resilient city untuk menciptakan kota dengan ketahanan pangan mandiri khususnya pada Kota Surakarta. Ketahanan pangan pada Kota Surakarta dapat diperoleh melalui sistem pertanian urban yang dapat dijalankan. Pertanian urban melibatkan produksi bahan pangan domestik di dalam atau berbatasan langsung dengan pemukiman di masyarakat. Pertanian urban dapat diimplementasikan melalui home farming dan community farming dengan berbagai metode tanam. Karena dengan adanya lahan terbatas di Kota Surakarta, penggunaan lahan yang dimanfaatkan untuk pertanian urban dapat dilakukan dengan metode tanam tanpa menggunakan tanah, serta menggunakan metode vertikultur. Metodologi penelitian yang digunakan adalah penelitian yang berdasarkan studi literatur melalui pendekatan pengembangan kota, yaitu pengembangan kota dari sudut pandang ekologi. Beberapa potensi bahan pangan yang dapat mewujudkan ketahanan pangan berkelanjutan di Kota Surakarta meliputi porang, ubi jalar, ubi kayu, talas, dan beberapa jenis sayuran. Penanaman beberapa bahan pangan tersebut memanfaatkan penggunaan lahan yang terbatas, namun mudah dilaksanakan bagi masyarakat Kota Surakarta. Penelitian ini bertujuan untuk mengkaji berbagai pendekatan yang dapat diterapkan pada Kota Surakarta dalam ketahanan terhadap pandemi, khususnya pandemi Covid-19. Dengan perancangan kota dengan konsep kota tangguh, hal ini akan menghasilkan solusi agar masyarakat Kota Surakarta dapat mandiri dalam memenuhi kebutuhan pangan secara berkelanjutan.
\end{abstract}

Kata kunci: ketahanan pangan; Kota Surakarta; pertanian urban; resilient city

\begin{abstract}
The development of resilient city concept in the pandemic era can be the major concept to be implemented for city planning. Resilient city is expected to be a reference for effective land use management. The agricultural sector can be one of the components in developing the concept of a resilient city to create food security, especially in the Surakarta City. Food security in Surakarta can be achieved through an urban farming system. Urban agriculture involves domestic food production within or directly adjacent to community settlements. Urban agriculture can be implemented through home farming and community farming with various planting methods. Due to the limited land in Surakarta, planting methods can be done without using any soil, and implementing the verticulture method. The study applies literature studies through a city development approach, namely city development from an ecological point of view. Several potential foodstuffs that can achieve food security in Surakarta are among others porang, sweet potato, cassava, taro, and several types of vegetables. Planting some of these foodstuffs utilizes limited land, but it is easy to implement. This study aims at examining various approaches that can be applied to the City of Surakarta to achive certain level of resilience to pandemics, especially the Covid-19 pandemic. It is expected that designing a city in accordance to the concept of resilient city will offer a solution to form an independent city in terms of meeting their daily food stuff sustainably.
\end{abstract}

Keywords: food security; Surakarta city; resilient city, urban agriculture 


\section{PENDAHULUAN}

Resilience (ketahanan) kota dapat didefinisikan sebagai kemampuan suatu sistem, komunitas, atau masyarakat kota yang terpapar bahaya untuk melawan, menyerap, mengakomodir, dan memulihkan dari efek bahaya secara tepat waktu dan efisien melalui pemulihan struktur dan fungsi kota yang penting (UNISDR, 2009). Kota tangguh atau resilient city merupakan suatu konsep kota mandiri yang dapat memenuhi semua kebutuhan hidup para penduduknya dengan komponen yang ada di dalamnya. Kota yang tangguh dalam paper ini ditekankan pada ketahanan pangan, karena komponen ini merupakan hal pokok dari kehidupan dinamis dalam suatu kota termasuk di Kota Surakarta.

Kota Surakarta merupakan salah satu kota yang terletak di Provinsi Jawa Tengah dengan potensi pusat urbanisasi yang lekat. Pandemi Covid-19 mengakibatkan tatanan kehidupan di seluruh dunia berubah, tak terkecuali di Surakarta. Dinamika yang mungkin terjadi di Kota Surakarta akibat adanya Covid-19 adalah ketersediaan pangan, sanitasi, energi, pendidikan, dan transportasi yang layak. Pandemi sebagai suatu bencana dapat dicegah dan diminimalisir dampaknya melalui perencanaan dan perancangan sistem perkotaan yang mampu mewujudkan kemandirian dan tangguh dari bencana. Ketahanan tersebut dapat dibentuk salah satunya dengan konsep ketahanan pangan untuk menjamin ketersediaan pangan bagi kehidupan masyarakat.

Ketahanan pangan (food security) berarti konsep yang fleksibel sebagaimana tercermin dari banyaknya upaya untuk mendefinisikannya dalam penelitian dan penggunaan kebijakan (Peng \& Berry, 2019). World Food Summit tahun 1996 mengartikan bahwa ketahanan pangan terjadi apabila semua orang, setiap saat, memiliki akses fisik dan ekonomi terhadap makanan yang sehat dan bergizi yang memenuhi kebutuhan makanan untuk kehidupan masyarakat yang aktif dan sehat (Food and Agriculture Organization, 2008). Perkotaan yang baik harus mempunyai kebutuhan pangan yang terjamin sehingga tidak terjadi permasalahan kelaparan pada penduduknya. Kebutuhan pangan yang berkelanjutan adalah kunci agar kebutuhan pangan penduduk suatu kota selalu terpenuhi kebutuhannya. Ketahanan pangan untuk Kota Surakarta tidak dapat diciptakan oleh produksi sendiri, melainkan selalu mengandalkan daerah lain seperti Kabupaten Klaten, Kabupaten Sukoharjo, dan Kabupaten Karanganyar. Ketiga kabupaten tersebut berguna untuk memenuhi kebutuhan makanan pokok di Surakarta untuk kebutuhan pangan berupa nasi dan kentang. Hal tersebut diakibatkan tidak adanya lahan pertanian di wilayah Surakarta karena kota yang bersifat dinamis menciptakan perubahan alih fungsi lahan yang berdampak pada tidak adanya kawasan pertanian, sehingga sulit untuk mengembangkan pertanian secara mandiri (Rubiantoro \& Haryanto, 2013).

Penelitian ini diharapkan dapat menjadi rujukan dalam pengembangan kota tangguh yang berfokus pada ketahanan pangan di Kota Surakarta. Pada saat pandemi, tidak bisa dipungkiri jika akses keluar masuk wilayah yang dibatasi turut menyulitkan distribusi barang dan jasa sehingga setiap kota harus bisa memenuhi kebutuhan pokoknya masing-masing. Apabila Kota Surakarta telah mencapai ketahanan pangan dengan pertanian mandiri, maka tidak perlu untuk terlalu bergantung untuk mendatangkan pasokan bahan pangan dari luar daerah. Tujuan dari penelitian ini juga dimaksudkan untuk mengkaji berbagai pendekatan yang dapat diterapkan pada Kota Surakarta dalam ketahanan terhadap pandemi, khususnya pandemi Covid-19. Dengan perancangan kota berbasis kota tangguh, diharapkan mampu memberikan solusi bagi masyarakat Kota Surakarta sehingga dapat mandiri dalam memenuhi kebutuhan pangannya.

\section{KAJIAN PUSTAKA}

\subsection{PERENCANAAN KOTA SURAKARTA}

Surakarta merupakan salah satu kota yang terletak di Provinsi Jawa Tengah dengan luas wilayah 44,04 km². Kepadatan penduduk di Kota Surakarta tergolong cukup tinggi, dengan jumlah penduduk 519 ribu jiwa dan kepadatan penduduknya mencapai 11.798 penduduk per km² (BPS Kota Surakarta, 2020). Dengan luas wilayah tersebut, Kota Surakarta terbagi menjadi lima wilayah kecamatan yaitu Kecamatan Laweyan, Serengan, Pasar Kliwon, Jebres, dan Banjarsari. Dalam pelaksanaannya, rencana tata ruang Kota Surakarta diatur dalam Peraturan Daerah No. 1 Tahun 2012 tentang Rencana Tata Ruang dan Wilayah Surakarta Tahun 2011-2031. Peraturan daerah tersebut bertujuan untuk mewujudkan Surakarta menjadi kota yang berbudaya, produktif, berkelanjuatan, dan berbasis lingkungan (Wiratama, Prihatin, \& Hardjanto, 2016). Untuk mewujudkan tujuan penataan ruang wilayah Surakarta, dilakukan kebijakan dan strategi penataan ruang kota yang meliputi kebijakan dan strategi pengembangan struktur ruang serta kebijakan dan strategi pengembangan pola ruang. Dengan 
melakukan perencanaan dan penataan kota, maka wilayah kota tersebut dapat ditentukan standar kualitas pemukiman dari kota tersebut (Prasetyo \& Rahayu, 2013).

Perencanaan tata kota perlu memerhatikan beberapa hal, diantaranya adalah (1) penggunaan tekonologi yang selektif disertai dengan pengawasan; (2) peningkatan usaha penelitian, penerangan, dan pelatihan yang berguna untuk meningkatkan kesadaran semua pihak terhadap kelestarian lingkungan perkotaan (Wilonoyudho, 2007), serta (3) rehabilitasi, restorasi, dan mitigasi yang harus dilakukan apabila terjadi bencana (pandemi). Seiring dengan berjalannya waktu, suatu kota akan mengalami perubahan yang dipengaruhi oleh perubahan global dan bencana yang mungkin terjadi. Bencana alam berupa banjir, longsor, gempa bumi, dan tsunami maupun bencana akibat faktor manusia (antropogenik) dalam bentuk konflik dan terosisme selalu mengancam kehidupan di suatu perkotaan (Setiadi \& Wulandari, 2016). Bencana berupa pandemi yang dampaknya terasa di seluruh dunia juga termasuk ke dalam ancaman bagi kehidupan perkotaan, tak terkecuali bagi Kota Surakarta pada tahun 2020.

\subsection{KONSEP KOTA TANGGUH}

Kota tangguh merupakan konsep ketahanan perkotaan terhadap keberagaman tingkat sosial mulai dari individu, keluarga, kelompok, organisasi, komunitas, hingga masyarakat global. Kota Surakarta perlu dirancang ulang dengan konsep resilient untuk mencapai ketahanan kota yang berguna bagi pelestarian ekosistem, energi, udara, dan pangannya. Sebagai kota dengan warisan budaya yang beragam, konsep kota tangguh yang dirancang untuk Surakarta perlu digabungkan antara pelestarian budaya, warisan, dan ketahanan psikologis masyarakatnya untuk menciptakan kehidupan kota yang mandiri dalam pandemi Covid-19. Kota tangguh diperlukan untuk mendukung strategi awal pada konsep ketahanan dan tahap pencegahan untuk mendefinisikan pada rencana mitigasi risiko dari bencana yang akan terjadi pada suatu kota (Žilènienè \& Fabirizo, 2014). Upaya mitigasi bencana dikatakan berhasil apabila prediksi dan penataan ruang kota dapat mengantisipasi potensi-potensi bencana yang akan terjadi (Wikantiyoso, 2010). Konsep kota tangguh di Surakarta menggunakan tata kelola kota untuk mengatasi ketidakpastian dan dampak lingkungan yang dapat terjadi di masa yang akan datang. Konsep pencegahan yang diterapkan pada kota tangguh berupa tindakan mitigasi dan adaptasi energi bersih dengan menggunakan metode restrukturisasi. Metode restrukturisasi pada tata kelola kota yaitu perencanaan kota yang mampu menahan, menyerap, mengakomodasi, dan pulih dari efek bahaya bencana secara tepat waktu dan efisien dengan tetap melakukan pelestarian struktur dasar kota yang sebelumnya telah ada (Jabareen, 2013).

\subsection{PERTANIAN URBAN DAN KETAHANAN PANGAN}

Krisis pangan yang terjadi akibat adanya suatu bencana (pandemi) dapat ditandai dengan melonjaknya harga-harga pangan dunia seperti makanan pokok berupa gandum, kedelai, beras, dan jagung. Penurunan pasokan bahan makanan tersebut berdampak pada harga pangan di pasar dunia yang semakin melambung, kemudian akan disusul dengan adanya kelangkaan bahan pangan. Maka dari itu, perlu adanya ketahanan pangan secara mandiri yang telah diatur dalam PP No. 68 Tahun 2002 tentang Ketahanan Pangan. Ketahanan pangan adalah kondisi terpenuhinya kebutuhan gizi setiap individu baik dalam jumlah maupun mutu agar dapat hidup aktif dan sehat secara berkesinambungan sesuai dengan budaya setempat (Rosyadi \& Purnomo, 2012).

\section{METODE PENELITIAN}

Paper ini disusun berdasarkan metode penelitian kepustakaan (library research), yaitu serangkaian penelitian yang berkenaan dengan metode pengumpulan data dan objek penelitiannya dilakukan melalui beragam informasi kepustakaan. Setelah sumber-sumber data didapatkan, penulis melakukan sintesis dan analisis agar literatur yang digunakan hanya yang berkaitan dengan konsep kota tangguh, ketahanan pangan, serta pertanian urban. Adapun penelitian kepustakaan atau kajian literatur (literature review) pada paper ini dilakukan menggunakan pendekatan strategi pengembangan kota, khususnya dari sudut pandang ekologi. Secara khusus, paper ini menggunakan penelitian Setiadi dan Wulandari (2016) sebagai landasan untuk mewujudkan suatu kota menjadi kota tangguh.

Penelitian pada paper ini dibatasi pada objek penelitian seputar pertanian urban, sehingga dapat diketahui strategi untuk mewujudkan ketahanan pangan di Kota Surakarta. Bagi perencana kota, pendekatan ini sangat diperlukan dalam upaya merencanakan dan merancang kota agar mampu merespon dinamika global berupa permasalahan yang dapat timbul akibat 
pandemi. Paper ini dibahas dalam 5 bagian. Bagian pertama berupa pendahuluan. Bagian kedua berisi konsep kota tangguh (resilient city), dimana pada bagian ini mengkaji konsep para peneliti untuk pembangunan kota tangguh. Bagian tiga berisi studi kasus penyusunan sistem tata kota tangguh melalui ketahanan pangan dan energi di Surakarta yang dikolaborasikan. Penulis menyimpulkan di bagian akhir, yaitu berupa jawaban atas pertanyaan untuk menjawab rumusan masalah.

\section{HASIL DAN PEMBAHASAN}

\subsection{KETAHANAN PANGAN}

Konsep resilient city atau kota tangguh yang akan diterapkan di Kota Surakarta adalah berfokus pada ketahanan pangan. Ketahanan pangan yang dimaksud disini adalah setiap penduduk kota dapat memiliki sumber pangan yang berkelanjutan, sehingga diharapkan terjadi kemerataan dalam mendapatkan pangan sehingga tercipta keseimbangan. Ketahanan pangan ini sangat penting, dimana selain makanan merupakan kebutuhan dasar manusia, ketahanan pangan juga diperlukan untuk menyokong perputaran roda kehidupan dan menyambut generasi yang akan datang di masa depan. Perencanaan akan ketahanan pangan sudah digemborkan sejak lama, namun realisasinya belum dapat berjalan baik. Jika melihat rencana lumbung pangan yang diterapkan pemerintah, program yang dijalankan malah merubah tatanan rona lingkungan suatu wilayah dimana hal ini akan mengganggu ekosistem tersebut dan tidak tercipta kesesuaian, contohnya saja adalah pengubahan lahan gambut menjadi lahan untuk pertanian.

Permasalahan yang dialami Kota Surakarta dalam mewujudkan rencana ketahanan pangan dalam konsep kota tangguh ini adalah tidak tersedianya lahan pertanian yang memadai. Hal ini karena Surakarta telah menjelma menjadi kota yang dinamis dan tergolong dalam lingkungan urban yang didominasi permukiman sehingga hanya tersisa sedikit lahan pertanian, bahkan cenderung tidak ada. Dengan keadaan seperti ini maka Surakarta mengekspor kebutuhan pangan yang belum tersedia dengan baik ke beberapa daerah di sekitarnya seperti Kabupaten Karanganyar dan Sukoharjo. Hal ini tentu cukup berisiko dimana kota ini belum mampu untuk memproduksi bahan pangan secara mandiri padahal penduduk kota setiap tahunnya akan semakin terus bertambah. Hal ini tentu saja dapat berpotensi untuk menimbulkan kekurangan pangan apabila sektor ekspor dari daerah lain terhenti akibat suatu permasalahan.

Maka dalam konsep ketahanan pangan ini direncanakan untuk membuat pertanian sendiri di lahan perkotaan yang sudah tersedia. Membuka pertanian sendiri, hal tersebut berarti membuka lahan pertanian mandiri dapat dilakukan di lahan kosong yang ada di area rumah. Lahan pertanian mandiri ini dinilai cukup efektif untuk diterapkan di kota-kota besar karena tidak membutuhkan lahan yang besar dalam penerapannya, dimana hal ini berkorelasi dengan luas wilayah Kota Surakarta yang terbatas. Setelah lahan pertanian mandiri ditentukan, maka selanjutnya adalah melakukan penanaman. Hal yang perlu diperhatikan adalah saat memilih vegetasi yang akan ditanam, dimana syarat-syarat yang harus terpenuhi adalah tahan akan penyinaran matahari sepanjang hari dan suhu perkotaan yang tinggi.

Kota Surakarta memiliki 5 kecamatan, yakni Jebres, Serengan, Laweyan, Pasar Kliwon, dan Banjarsari (Gambar 1). Bila kelima kecamatan ini dapat menerapkan sistem pertanian mandiri yang telah dikonsepkan dengan baik, maka ketahanan pangan akan menjadi senjata Kota Surakarta dalam mewujudkan kota yang tangguh. Dari kecamatan yang ada dapat ditentukan daerah mana yang bisa diaplikasikan sebagai sumber ketahanan pangan utama. Ketahanan pangan menjadi salah satu peran ekologis dalam menghasilkan lingkungan yang berkelanjutan. Selain itu, dampak positif lainnya bagi Surakarta bila dapat menerapkan ketahanan pangan adalah mempertahankan nutrisi dalam masyarakat dan mengedarkannya agar ketersedian pangan tetap terjaga. Dengan semakin berkembangnya industri dan pembangunan di Indonesia, lahan pertanian akan tersisih dan makanan yang berasal dari sumber alami akan menjadi hal yang sangat penting dan paling dicari oleh banyak orang. Kota dengan ketahanan pangan yang baik sejatinya perlu memiliki sistem pertanian sendiri, terlepas dari berbagai kendala serta permasalahan perkotaan di dalamnya. Hal ini karena pertanian merupakan aspek penting dalam menghasilkan ketahanan pangan mandiri dimana menghasilkan bahan-bahan esensial seperti sumber tenaga berupa karbohidrat dan sumber protein serta vitamin.

Pertanian urban telah lama dikenal karena peran pentingnya sebagai strategi kelangsungan hidup di perkotaan. Pertanian urban melibatkan produksi bahan pangan domestik di dalam atau berbatasan langsung dengan permukiman perkotaan yang padat dan dinamis. Pertanian urban memainkan peran kunci dalam mengurangi pengeluaran terhadap bahan pangan, serta 
berfungsi sebagai sumber pendapatan sebagai bagian dari diversifikasi mata pencaharian. Dalam paper ini, pertanian urban ditujukan untuk mencapai kemandirian pangan bagi warga Kota Surakarta sehingga tidak terlalu bergantung pada daerah lain dalam upaya pemenuhan bahan pangan.

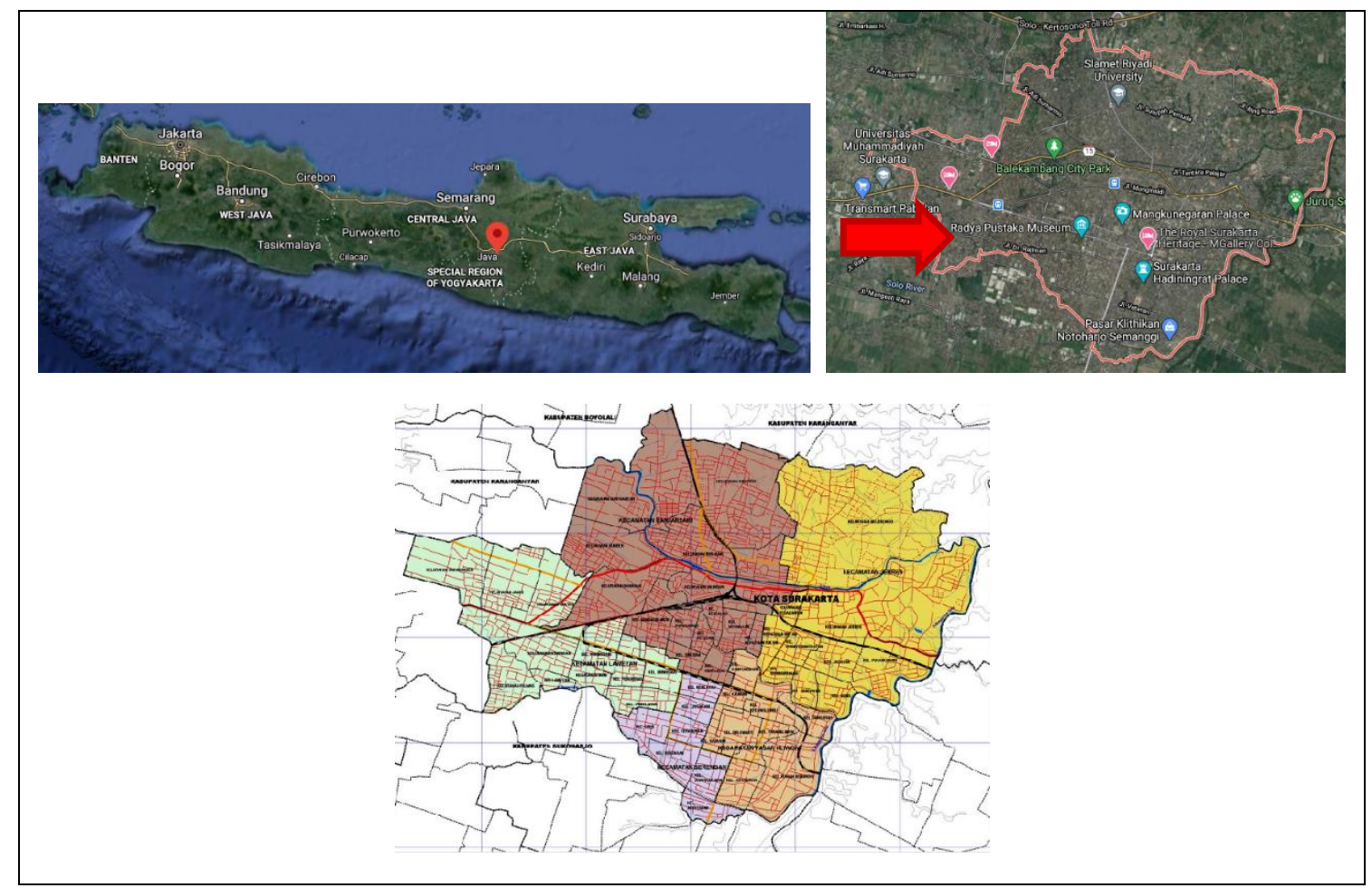

Gambar 1. Pembagian Administrasi Kota Surakarta

Penanaman di lahan sempit bisa dengan menggunakan teknik vertikultur, dimana dengan menggunakan teknik ini, pemanfaatan lahan bisa digunakan secara optimal. Teknik vertikultur bisa menanam 20-30 tanaman dalam lahan sebesar 50 $\mathrm{cm} \times 50 \mathrm{~cm}$. Hal paling penting dari penanaman di lahan sempit adalah menyesuaikan luas dan kondisi lahan dengan jenis tanaman yang akan ditanam. Contoh tanaman yang sesuai untuk ditanam di lahan sempit adalah porang, kangkung, bayam, cabai, selada, dan pare. Sebelum menanam, sangat penting untuk mengetahui keadaan lahan yang akan ditanami. Misalkan pada tanah dengan pH 6-7 maka cocok untuk ditanami cabai dan sawi. Jika terdapat lahan berukuran kurang lebih $100 \mathrm{~m}^{2}$, maka dapat menggunakan sistem penanaman tumpangsari, yaitu satu jenis tanaman tumbuh pendek dan jenis lainnya dapat tumbuh lebih tinggi. Kemudian ada pula cara lain yaitu memodifikasi teknik penanaman secara vertikultur, yaitu dengan dikolaborasikan dengan sistem hidroponik. Pemodifikasian ini tentu juga harus diikuti dengan tanaman yang sesuai, seperti selada.

Pertanian urban telah lama dikenal karena peran pentingnya sebagai strategi kelangsungan hidup di perkotaan. Pertanian urban melibatkan produksi bahan pangan domestik di dalam atau berbatasan langsung dengan pemukiman. Pertanian urban memainkan peran kunci dalam mengurangi pengeluaran terhadap bahan pangan, serta berfungsi sebagai sumber pendapatan sebagai bagian dari diversifikasi mata pencaharian. Dalam paper ini, pertanian urban ditujukan untuk mencapai kemandirian pangan bagi warga kota sehingga tidak terlalu bergantung pada daerah lain dalam pemenuhan bahan pangan.

\subsection{SISTEM PERTANIAN URBAN MENURUT PELAKU}

\subsubsection{Home Farming (Bertani Skala Rumah Tangga)}

Berkebun di rumah adalah fenomena populer di seluruh dunia melalui bagi semua lapisan masyarakat dan merupakan bentuk pertanian perkotaan yang paling umum (Neergaard, Drescher, \& Kouamé, 2009). Kedekatan kebun dengan rumah, budidaya aneka bahan pangan, dan pemanfaatan bahan pangan dengan biaya rendah umumnya dianggap sebagai 
karakteristik dasar untuk bertani dari rumah. Produksi biasanya lebih bersifat pelengkap pangan daripada menjadi sumber utama untuk konsumsi (Galhena et al. 2013). Manfaat yang paling penting adalah penyediaan bahan pangan berupa sayuran segar, penghematan biaya makan, dan pendapatan tambahan jika dijual (Oluoch et al., 2009).

\subsubsection{Community Farming (Bertani Skala Komunitas)}

Bertani dalam skala komunitas berarti budidaya tanaman secara kolektif oleh sekelompok orang dalam satu wilayah. Kelompok tersebut berasal dari perkumpulan masyarakat yang sangat erat dengan kegiatan bersama, hingga kelompok yang hanya berbagi fasilitas untuk bertani (Neergaard et al., 2009). Bertani dalam skala komunitas mengharuskan masyarakat untuk mengelola perkebunannya bagi kepentingan bersama sehingga tanaman pangan yang ditanamnya tidak menentu. Melalui kebun masyarakat, warga memiliki kesempatan untuk menggunakan tanah bersama atau bersubsidi sehingga dalam pengelolaannya tidak terlalu membutuhkan biaya besar, namun dengan hasil maksimal. Banyak negara di dunia seperti Sri Lanka, Argentina, dan Madagaskar mempromosikan program bertani di sekolah. Program-program ini dirancang untuk membekali siswa dengan pendidikan dan berkebun untuk menghasilkan makanan segar dan sehat dimana hal tersebut berperan penting untuk memenuhi kebutuhan gizi dan ketahanan pangan (Dubbeling, Veenhuizen, \& Zeeuw, 2010).

\subsection{SISTEM PERTANIAN URBAN MENURUT MEDIA TANAM}

\subsubsection{Bertani Tanpa Tanah}

Istilah "bertani tanpa tanah" diartikan sebagai budidaya tanaman dalam sistem tanpa media tanah. Dalam beberapa tahun terakhir banyak inovasi budidaya menggunakan tas, ember, hingga pipa dengan ditambah nutrisi untuk mengembangkan media bertani dan berkebun tanpa tanah. Metode budidaya ini termasuk sistem tanpa media tanah padat atau agregat tanah, dimana substrat anorganik atau organik digunakan untuk tanaman (Gruda \& Tanny, 2014). Bertani tanpa tanah cocok untuk diterapkan dalam pertanian urban, terutama dalam hal efisiensi sumber daya dan keberlanjutannya. Metode bertani tanpa tanah memiliki beberapa contoh implementasi, antara lain:

a) Hidroponik, yaitu bahan pangan berupa sayuran ditanam di air yang mengandung mineral dan nutrisi yang dibutuhkan oleh tanaman. Hidroponik sama seperti pertanian urban pada umumnya yang berfungsi untuk menumbuhkan bahan pangan pelengkap (bukan utama).

b) Sistem akuaponik, terdiri dari satu unit hidroponik yang membudidayakan sayuran dan unit budidaya ikan. Air limbah dari ikan bergerak melalui saluran hidroponik kemudian bagian kotoran ikan dikeluarkan untuk dijadikan nutrisi bagi tanaman. Jenis produksi ini memungkinkan produksi sekaligus untuk sayuran dan ikan dengan siklus yang beriringan. Fitur ini membuat akuaponik sangat berkelanjutan dalam hal daur ulang nutrisi dan air.

\subsubsection{Vertikultur}

Penanaman bahan pangan secara vertikal. Konsep pertanian urban yang paling kompleks dan futuristik pertanian adalah konsep vertikultur. Produksi tanaman dengan sistem vertikultur memungkinkan area budidaya menjadi lebih luas, meskipun di lahan sempit. Dengan penanaman secara vertikultur, maka penanaman dengan menggunakan media seperti talang air dan kayu dapat dilakukan, sehingga dapat bertani dengan berkreativitas dan memaksimalkan bahan-bahan yang sudah ada.

\subsection{UMBI-UMBIAN SEBAGAI SUMBER PANGAN UTAMA}

Dalam konsep resilient city yang akan dikembangkan di Kota Surakarta, ketahanan pangan menjadi kunci dari konsep ini. Dalam ketahanan pangan di Kota Surakarta, pemanfaatan lahan kosong untuk ditanami berbagai jenis tanaman adalah hal yang harus dilakukan. Kunci dari sumber pangan adalah makanan yang mengandung karbohidrat, karena akan menghasilkan energi yang dibutuhkan oleh tubuh. Sebagai alternatif menggantikan padi yang membutuhkan area penanaman, yaitu sawah yang luas, maka dikembangkan ide untuk membudidayakan tanaman umbi-umbian.

Dalam mengembangkan sumber pangan pengganti beras, maka dibutuhkan pengujian terhadap kualitas dan kandungan yang dimiliki. Menurut Lukitaningsih dkk. (2012), untuk dapat menggantikan beras sebagai makanan pokok, perlu melakukan 
uji makronutrien di sejumlah makanan umbi-umbian tertentu. Kandungan karbohidrat, protein, dan serat, dimana berfungsi dalam sintesis karbohidrat kompleks seperti amilum. Selain itu, kandidat pengganti beras sebagai bahan makanan pokok harus memperhatikan kandungan indeks glikemik agar dapat dikonsumsi oleh penderita diabetes mellitus. Beberapa bahan makanan yang memiliki indeks glikemik rendah adalah porang dan walur (Tabel 1).

Tabel 1. Perbandingan Kandungan Porang dengan Umbi Lainnya

\begin{tabular}{cccc} 
Nama & Indeks glisemik & $\begin{array}{c}\text { Kandungan } \\
\text { serat kasar }(\%)\end{array}$ & $\begin{array}{c}\text { Kandungan } \\
\text { protein (\%) }\end{array}$ \\
\hline Porang & 20,6 & $15,09 \pm 2,25$ & $4,32 \pm 0,23$ \\
Walur & 16,9 & $11,27 \pm 0,43$ & $8,72 \pm 0,47$ \\
Beras & 72,8 & $1,32 \pm 0,02$ & $0,76 \pm 0,12$ \\
\hline
\end{tabular}

Dari Tabel 1 dapat diketahui bahwa kandungan indeks glisemik porang dan walur lebih rendah dari yang terdapat pada beras, yaitu masing-masing berkisar pada angka 20,6 dan 16,9. Hal ini berarti porang dan walur sangat direkomendasikan untuk dikonsumsi sebagai bahan makanan pengganti beras, terutama untuk penderita diabetes mellitus yang membutuhkan makanan dengan indeks glisemik yang rendah. Kandungan serat kasar pada porang dan walur lebih besar dibandingkan beras, begitu pula dengan kandungan proteinnya.

Salah satu tanaman yang bisa dikembangkan adalah porang. Porang dipilih karena merupakan tanaman umbi-umbian yang mengandung karbohidrat yang berguna sebagai sumber tenaga. Tanaman porang dipilih karena area lahan yang terbatas di perkotaan sehingga tidak memungkinkan untuk melakukan penanaman padi. Porang merupakan salah satu jenis umbi-umbian yang umum diolah menjadi berbagai macam bahan pangan. Porang (Amorphophallus muelleri) merupakan tanaman herba familia Araceae yang umbinya dapat dipanen pada akhir musim kemarau. Umbi porang mengandung asam oksalat yang terdiri dari oksalar larut air dan oksalat tidak larut air. Kandungan asam oksalat ini membuat porang memiliki manfaat seperti pengikat racun oksalat dan meregulasi kalsium (Ardhian \& Indriyani, 2013).

Selain itu, umbi porang juga mengandung kadar glukomanan yang cukup tinggi, dimana $15-64 \%$ berbasis kering. Glukomanan merupakan bahan dengan kandungan serat larut air yang tinggi, rendah akan kalori, dan bersifat hidrokoloid. Zat ini dapat digunakan sebagai anti diabetes, hipertensi, dan kolesterol. Porang yang memiliki sifat mudah mengikat air dapat diolah sebagai tepung yang akan menghasilkan tepung porang serta dapat dibuat sebagai bahan tambahan dalam berbagai makanan seperti mi dan pasta. Porang sangat baik digunakan sebagai makanan sumber energi pengganti nasi karena memiliki kadar karbohidrat yang dominan, yakni sebesar $31,33 \%$, lalu disusul oleh serat sebesar $22,34 \%$, kemudian protein dan lemak yang masing-masing memiliki kadar 1,05\% dan 0,5\% (Nugraheni, Setyopuspito, \& Advistasari, 2018).

Selanjutnya adalah walur, umbi-umbian ini juga dikenal sebagai iles-iles oleh beberapa kalangan masyarakat. Menurut Supriati (2016), umbi ini dapat digunakan sebagai sumber pangan fungsional, yang berarti selain dapat digunakan sebagai sumber pangan penghasil energi juga mengandung nutrisi baik yang memberikan manfaat kesehatan. Walur juga bisa diolah menjadi tepung yang akan menghasilkan tepung konyaku yang bisa dibuat sebagai bahan pembuatan tahu.

Alternatif lain yang perlu diperhatikan adalah ubi jalar, dimana tanaman ini dapat menghasilkan kandungan karbohidrat yang lebih efisien daripada tanaman padi (Zuraida, 2009). Ubi jalar mengandung kalori, serat, vitamin, dan mineral. Keunggulan ubi jalar adalah mempunyai kandungan vitamin $\mathrm{A}$ dan $\mathrm{C}$ lebih tinggi diantara umbi-umbian lainnya. Perbandingan kandungan umbu-umbian dapat dilihat pada Tabel 2.

Tabel 2. Perbandingan Kandungan Umbi-Umbian

\begin{tabular}{ccc} 
Nama makanan & $\begin{array}{c}\text { B-carotene } \\
\text { (mg/100 gr) }\end{array}$ & $\begin{array}{c}\text { Vitamin C } \\
\text { (mg/100 gr) }\end{array}$ \\
\hline Ubi jalar & 20 & 30 \\
Ubi kayu & 0,1 & 32 \\
Talas & 0 & 17 \\
\hline
\end{tabular}




\subsection{KONSEP KOTA TANGGUH DI KOTA SURAKARTA}

Konsep kota tangguh yang akan diterapkan di Kota Surakarta membagi kota ini menjadi beberapa wilayah. Kota Surakarta memiliki 5 kecamatan sehingga setiap kecamatan akan memiliki usaha penanaman komoditasnya masing-masing. Selain itu, wilayah kampus seperti halnya pada kampus UNS yang memiliki beberapa lahan kosong, dapat dimanfaatkan untuk penanaman komoditas yang menjadi fokus kecamatannya, yaitu Kecamatan Jebres. Meski terbatas, namun lahan kosong seperti pada lembah Fakultas Teknik dapat dicoba untuk digunakan sebagai media penanaman. Kampus UNS yang memiliki banyak pohon dan vegetasi menjadi acuan untuk penanaman komoditas ini, karena kawasan yang masih asri dan menghasilkan banyak oksigen alami akan menciptakan lingkungan yang baik untuk bercocok tanam.

Wilayah lain yang berpotensi untuk menjadi sentra ketahanan pangan adalah pada Kota Surakarta adalah pada Desa Ngemplak, Mojosongo, Kecamatan Jebres. Dengan melakukan salah satu bentuk implementasi RTH di kawasan permukiman berupa kegiatan pertanian perkotaan atau pertanian urban. Desa Ngemplak pada saat ini telah berada pada tahap yang memiliki ketahanan pangan skala wilayah sendiri dengan adanya pertanian urban. Ketahanan pangan tersebut dapat terbentuk dengan adanya pemberdayaan warga setempat melalui komonitas warga desa itu sendiri. Melalui sistem penanaman organik dan akuaponik, sayur menjadi komoditas unggul untuk mencukupi kebutuhan warga masyarakat setempat atau bahkan dapat dipasarkan karena kebutuhan warga yang telah tercukupi sebelumnya. Melakukan penanaman sendiri sayuran memiliki peranan strategis untuk meningkatkan keanekaragaman pola konsumsi pangan dan peningkatan gizi masyarakat. Dalam hal ini di Desa Ngemplak dapat berperan sebagai sumber bahan sayur-sayuran karena sistem penanaman organik dan akuaponik yang sudah diterapkan ternilai baik dan efektif dalam pemanfaatan tata ruang dan wilayah landscape desa tersebut. Selain itu, pertanian urban juga berkontribusi dalan pengurangan emisi karbon, mengurangi sampah rumah tangga, dan memunculkan kesan ramah lingkungan serta menambah nilai estetika dengan melalui vertikultur.

Sebagai sentra ketahanan pangan, untuk mewujudkan konsep kota tangguh secara umum, perlu diterapkan pertanian dengan perlakuan hidroponik ataupun vertikultur. Hal ini dilakukan guna memanfaatkan lahan yang terbatas dimana kawasan Kota Surakarta yang sudah didominasi oleh pemukiman dan kegiatan industri mengakibatkan lahan-lahan kosong semakin berkurang. Pertanian hidroponik ataupun vertikultur yang akan diterapkan dapat dipadukan dengan melakukan penanaman beberapa komoditas pangan yang telah disebutkan sebelumnya, seperti umbi-umbian macam porang dan ubi jalar ataupun tanaman lain seperti sayur selada dan cabai. Penanaman komoditas pangan tersebut dapat dilakukan secara individu di lahan rumah masing-masing ataupun dengan pertanian secara berkelompok, yaitu berdasarkan kesepakatan antara beberapa penduduk untuk melakukan penanaman dan mengelola suatu komoditas di sebuah lahan kosong. Hal ini penting karena jika dilakukan secara berkelanjutan dan konsisten, maka penduduk kota bisa memanen komoditas tersebut. Selain sayur, penanaman umbi juga dapat dilakukan seperti contohnya adalah porang yang memasuki masa panen setelah 6 bulan penanaman. Selain itu, setiap rumah penduduk akan memiliki sistem penanaman masing-masing di rumahnya. Kunci dari penanaman mandiri ini adalah memaksimalkan luas lahan yang terbatas dan jenis tanaman yang akan ditanam, seperti yang sudah dipaparkan di atas.

\section{KESIMPULAN}

Kota surakarta adalah salah satu kota yang berpotensi menjadi salah satu kota resilient yang berfokus pada ketahanan pangan masyarakat di era pandemi. Pertanian urban adalah strategi penting dalam kelangsungan hidup masyarakat di perkotaan dengan melibatkan produksi bahan pangan domestik di dalam atau berbatasan langsung dengan pemukiman. Pertanian urban memainkan peran kunci dalam mengurangi pengeluaran terhadap bahan pangan serta berfungsi sebagai sumber pendapatan sebagai bagian dari diversifikasi mata pencaharian. Pertanian urban ditujukan untuk mencapai kemandirian pangan bagi warga kota sehingga tidak terlalu bergantung pada daerah lain dalam pemenuhan bahan pangan. Pada Kota Surakarta, pertanian urban guna menyokong ketahanan pangan dapat dilakukan dengan teknik hidroponik, akuaponik, dan vertikultur guna memanfaatkan ruang lahan yang tersisa dengan maksimal. Penanaman yang dilakukan meliputi umbi seperti porang dan beragam sayur mayur guna menyokong ketahanan pangan kota ini. Dengan adanya ketahanan pangan mandiri maka tidak akan terjadi krisis pangan yang mengintai pada saat pandemi ini atau pandemi-pandemi yang akan datang karena kebutuhan pangan masyarakat dapat disuplai secara mandiri. 
Desa-Kota, Vol. 3, No. 2, 2021, 162-170

\section{DAFTAR PUSTAKA}

Ardhian, D., \& Indriyani, S. (2013). Kandungan Oksalat Umbi Porang (Amorphophallus muelleri Blume) Hasil Penanaman dengan Perlakuan Pupuk P dan K. Jurnal Biotropika, 1(2), 53-56. Diakses dari https://biotropika.ub.ac.id/index.php/biotropika/article/view/134

BPS Kota Surakarta. (2020). Kota Surakarta Dalam Angka 2020. Surakarta: BPS Kota Surakarta. Diakses dari https://surakartakota.bps.go.id/publication/2020/02/28/5a307392dc90b6daad9bb999/kota-surakarta-dalam-angka-2020-penyediaan-data-untuk-perencanaan-pembangunan.html

Dubbeling, M., Veenhuizen, R. van, \& Zeeuw, H. de. (2010). Cities , Poverty and Food: Multi-Stakeholder Policy and Planning in Urban Agriculture Marielle. Rugby: Practical Action Publishing. Diakses dari https://ruaf.org/assets/2019/11/Cities-Poverty-and-Food.pdf

Food and Agriculture Organization. (2008). An Introduction to the Basic Concepts of Food Security (Vol. 95). EC - FAO Food Security Programme. Diakses dari EC - FAO Food Security Programme website: http://www.fao.org/3/al936e/al936e.pdf

Gruda, N., \& Tanny, J. (2014). Protected Corps. In G. R. Dixon \& D. E. Aldous (Eds.), Horticulture: Plants for People and Places, Volume 1 (pp. 327-405). Dordrecht: Springer.

Jabareen, Y. (2013). Planning the resilient city: Concepts and Strategies for Coping With Climate Change and Environmental Risk. Cities, 31, 220-229. https://doi.org/10.1016/j.cities.2012.05.004

Lukitaningsih, E. (2012). Kajian Glisemik Indeks Dan Makronutrien Dari Umbi-Umbian Dalam Upaya Pencarian Sumber Pangan. Pharmacon: Jurnal Farmasi Indonesia, 13(1), 18-23. https://doi.org/10.23917/pharmacon.v13i1.22

Neergaard, A. de, Drescher, A. W., \& Kouamé, C. (2009). Urban and Peri-Urban Agriculture in African Cities. In C. M. Shackleton, M. W. Pasquini, \& A. W. Drescher (Eds.), African Indigenous Vegetables in Urban Agriculture (pp. 67-96). London: Routledge. https://doi.org/10.4324/9781849770019

Nugraheni, B., Setyopuspito, A., \& Advistasari, Y. D. (2018). Identifikasi dan Analisis Kandungan Makronutrien Glukoman Umbi Porang (Amorphophallus onchophyllus). JIFFK: Jurnal IImu Farmasi Dan Farmasi Klinik, 15(2), 77-82. https://doi.org/10.31942/jiffk.v15i2.2570

Oluoch, M. O., Pichop, G. N., Silué, D., Abukutsa-Onyango, M. O., Diouf, M., \& Shackleton, C. M. (2009). Production and harvesting systems for African indigenous vegetables. In C. M. Shackleton, M. W. Pasquini, \& A. W. Drescher (Eds.), African Indigenous Vegetables in Urban Agriculture (pp. 145-175). London: Earthscan. https://doi.org/10.4324/9781849770019

Peng, W., \& Berry, E. M. (2019). The Concept of Food Security. In P. Ferranti, E. M. Berry, \& J. R. Anderson (Eds.), Encyclopedia of Food Security and Sustainability (Vol. 2, pp. 1-7). Elsevier. https://doi.org/10.1016/B978-0-08-100596-5.22314-7

Prasetyo, W. T., \& Rahayu, S. (2013). Kajian Kualitas Permukiman Dengan Citra Quickbird Dan Sig Di Kecamatan Serengan Kota Surakarta. Teknik Perencanaan Wilayah Kota, 2(2), 293-302. Diakses dari https://ejournal3.undip.ac.id/index.php/pwk/article/view/2388

Rosyadi, I., \& Purnomo, D. (2012). Tingkat Ketahanan Pangan Rumah Tangga di Desa Tertinggal. Jurnal Ekonomi Pembangunan, 13(2), 303-315. https://doi.org/10.23917/jep.v13i2.176

Rubiantoro, E. A., \& Haryanto, R. (2013). Bentuk Keterlibatan Masyarakat dalam Upaya Penghijauan pada Kawasan Hunian Padat di Kelurahan Serengan - Kota Surakarta. Jurnal Pembangunan Wilayah \& Kota, 9(4), 416-428. https://doi.org/10.14710/pwk.v9i4.6679

Setiadi, R., \& Wulandari, F. (2016). Memadukan Strategi, Mewujudkan Ketahanan: Sebuah Pembelajaran dari Pengembangan Strategi Ketahanan Kota di Semarang. Jurnal Pengembangan Kota, 4(2), 95-105. https://doi.org/10.14710/jpk.4.2.95-105

Supriati, Y. (2016). Keanekaragaman lles-lles (Amorphophallus spp.) dan Potensinya untuk Industri Pangan Fungsional, Kosmetik, dan Bioetanol. Jurnal Penelitian Dan Pengembangan Pertanian, 35(2), 69-80. https://doi.org/10.21082/jp3.v35n2.2016.p69-80

United Nations International Strategy for Disaster Reduction. (2009). UNISDR Terminology on Disaster Risk Reduction. Geneva: UNISDR. Diakses dari https://www.unisdr.org/files/7817_UNISDRTerminologyEnglish.pdf

Wikantiyoso, R. (2010). Mitigasi Bencana di Perkotaan: Adaptasi atau Antisipasi Perencanaan dan Perancangan Kota ? (Potensi Kearifan Lokal Dalam Perencanaan dan Perancangan Kota Untuk Upaya Mitigasi Bencana). Local Wisdom, 2(1), 18-29. https://doi.org/10.26905/lw.v2i1.1368

Wilonoyudho, S. (2007). Perencanaan Kota Berbasis Manajemen Bencana. Jurnal Teknik Sipil Dan Perencanaan, 9(2), 163-170. https://doi.org/10.15294/jtsp.v9i2.1617

Wiratama, A., Prihatin, E. S., \& Hardjanto, U. S. (2016). Tugas Badan Perencanaan Pembangunan Daerah dalam Pelaksanaan Rencana Tata Ruang Wilayah Kota Surakarta Tahun 2011-2031. Diponegoro Law Journal, 5(3), 1-12. Diakses dari https://ejournal3.undip.ac.id/index.php/dlr/article/view/12129

Žilènienè, B. P., \& Fabirizo, T. (2014). Integrated Approach to a Resilient City: Associating Social, Environmental and Infrastructure Resilience in its Whole. European Journal of Interdisciplinary Studies, 6(2), 1-13. Diakses dari https://ejist.ro/files/pdf/383.pdf

Zuraida, N. (2009). Status Ubi Jalar sebagai Bahan Diversifikasi Pangan Sumber Karbohidrat. Iptek Tanaman Pangan, 4(1), 69-80. Diakses dari http://ejurnal.litbang.pertanian.go.id/index.php/ippan/article/view/2633 